\title{
Hermetiske reformationer i det 15.-16. århundrede
}

\author{
TIM RUDBØG
}

ENGLISH ABSTRACT: This article seeks to nuance the classic narrative of the Reformation in which Martin Luther is singled out and the Reformation, directly linked to Luther, is equally portrayed as a very specific singular event. Based on a perspective of pluralism this article shows that several reformative attempts inspired by Hermetism and the notion of a prisca theologia had already begun prior to Luther and was subsequently continued in connection with the Counter-Reformation and in other circles. Persons such as Marsilio Ficino and Pico della Mirandola and later heirs of Hermetism, are for example only very rarely mentioned directly in connection with the ongoing reformations of the Church. The reason why these persons are overlooked might be rooted in the concept of the Reformation itself and the Christian antipathy for the foreign pagan traditions by which these very persons sought to reform the Church.

DANSK RESUME: Denne artikel forsøger at nuancere den klassiske fortælling om Reformationen, hvor alene Martin Luther bliver fremhævet, og hvor Reformationen direkte forbundet med Luther ligeledes er afbilledet som en meget specifik og enkeltstående begivenhed. Baseret på et pluralistisk perspektiv viser artiklen, at flere forsøg på reformation af den kristne kirke, inspireret af hermetisme- og prisca theologia-tanken, allerede var begyndt for Luther og fortsatte efterfølgende i forbindelse med modreformationen og $i$ andre kredse. Personer som Marsilio Ficino og Pico della Mirandola samt senere hermetiske arvetagere bliver fx kun meget sjældent næont $i$ direkte forbindelse med de fortsatte reformationer af kirken. Grunden, til at disse personer traditionelt bliver overset, er måske rodfxstet $i$ selve reformationsbegrebet og den kristne antipati mod de fremmede hedenske traditioner, som netop disse personer forsøgte at reformere kirken med.

KEYWORDS: Reformation; Hermetism; Renaissance studies; esotericism

Uanset om talen falder på reformation eller Reformationen, og i særdeleshed ved protestantiske markeringer af den reformation, der blev udløst af den tyske teologiprofessor, komponist, præst og munk Martin Luther (1483-1546), er det netop personen Martin Luther, der kommer til at figurere fuldstændigt centralt i denne enestående begivenhed. Luther var den store reformator, der er kendt for sine 95 teser, som han 
ifølge traditionen den 31. oktober 1517 slog op på kirkedøren til Schlosskirche i Wittenberg. På dette tidspunkt blev denne kirkedør ofte brugt som en slags opslagstavle for universitetets undervisere, hvorfor det er nærliggende at forestille sig, at Luther netop her ønskede at indlede en debat om kirkens salg af afladsbreve. Om det historisk faktuelt var præcis således, det foregik, kan ikke med sikkerhed verificeres; men det kan det derimod, at han samme dag sendte et brev til ærkebiskop Albert af Mainz, hvori han udtrykte sin utilfredshed omkring praksissen med afladsbrevene. Denne kritik kom naturligvis også pave Leo X for øre, hvilket resulterede i, at paven i 1521 endte med at ekskommunikerede Luther, fordi han nægtede at frasige sig sine skrevne ord, og at kejser Charles V på samme baggrund ligeledes gjorde ham fredløs.

Denne artikels ærinde er en nærmere undersøgelse af netop det at fremhæve en enkeltstående historisk begivenhed som banebrydende, som her Luthers opslag af sine 95 teser, hvilket ud fra en streng historisk tilgang vil forsøges problematiseret og nuanceret en smule. Det følgende vil derfor være en kritisk gennemgang af en bredere og dog mindre kendt historisk sammenhæng, der ledte op til og fulgte efter det reformatoriske skæringspunkt, som afholdelser af reformationsjubilæer normalt markerer med én enkelt, stor historisk person i fokus.

\section{Reformationer}

I de senere år er nogle historikere begyndt at fokusere på reformationer i flertal og på 'the long reformation' i en lidt bredere forstand, hvor visse specialiststudier også graver ned i den baggrund, der ligger til grund for, at Martin Luther i det hele taget gik hen og blev en stor reformator (se Dixon 2012; Wallace 2004). I dette mere nuancerede historiske billede bliver der ofte talt om de tidlige reformationer, det vil sige i årene 1378-1416, med fx John Wycliffe (1320erne-1384) på Oxford og Jan Hus (1369-1415) i Prag, som begge i disse studier anses som en form for forgangsmænd for Luther. Herefter følger selvfølgelig Luther selv i samme fodspor. Dette billede taler også om en samtidig og fortsat reformation, den såkaldte magistrale reformation (McGrath 1998, 159), med Huldreich Zwingli (1484-1531) i Schweiz, som en stor reformationsskikkelse inden for kristendommen og, som bekendt, John Calvin (1509-1564) i Geneve, samt Philipp Melanchton (1497-1586) i Det Tysk-romerske Rige. Alle var de Luthers nogenlunde samtidige. Ud over disse er der tillige andre indflydelsesrige personer, som ofte bliver nævnt i forbindelse med Reformationen, så som Johannes Oecolamoadius (1482-1531) fra Basel og særligt også Desiderius Erasmus (1465/6-1531) fra Rotterdam, som i 1509 bidrog til debatten med sit skrift Stutitiae Laus or Moriae Encomium 'Tåbelighedens lovprisning'. Herefter følger de såkaldte radikale reformationer med Thomas Münzer (1489-1525) i Det Tysk-romerske Rige, Andreas Rudolph Bodenstein von Karlstadt (1486-1541), født i Karlstadt i Franken og bedre kendt som Andreas Karlstadt, og en lang række andre grupper som Zwickau-profeterne, Anabaptisterne, Hutteritterne og Mennonitterne. Kendt i forbindelse med de historiske nuancer er også modreformationen, som er den den romersk-katolske kirke lancerer 
for at modarbejde ovennævnte strømninger, hvorunder hører også dannelsen af Jesuiterordenen i 1534, hvor særligt dennes grundlægger teologen og præsten Ignatius Loyola (1491-1556) fra Spanien bør nævnes. I dette mere nuancerede historiske billede af reformationstiden er der dog også, som vi skal se nedenfor, en særlig række reformtiltag, som sjældent bliver nævnt i forbindelsen med Reformationen. Endvidere, på trods af, at nogle historikere er sig bevidste om, at reformation, i betydningen af at omforme en institution, er noget, flere religioner gennemgår løbende, og at der i tiden omkring Luther var flere tiltag til omformning af kirken, samt at en historisk kompleksitet af sammenhænge forårsagede en konkret splittelse af kirken, så befinder Luther sig ikke desto mindre i centrum af den gængse fortælling om Reformationen. Faktisk er det ikke uden en vis vanskelighed at fremskaffe et begreb om Reformation eller en beskrivelse af Reformationen, uden at Luther står i centrum. Dette gør sig ligeledes gældende inden for faglitteraturen. Til eksempel kan The Brill Dictionary of Religions nævnes, hvor indlægget om 'Reformation' nok så karakteristisk kun fokuserer på 'The Reformation radiating from Germany', hvor Luther er fremhævet, idet hans protest "became the initial event of the Reformation" (Leppin 2006, 1596-97). I det store værk i De Gruyters reference series om Martin Luther: A Christian between Reforms and Modernity (1517-2017) nævnes ligeledes på intet tidspunkt hermetiske tankesæt eller skikkelser som den florentinskfødte, katolske præst og renæssancemand Marsilio Ficino (1433-1499), imens andre forgængere eller reformatoriske efterkommere, der står i denne tankestrømning, kun sporadisk tages i betragtning (Melloni 2017).

Først når vi bevæger os hen i den mere omfattende nye Oxford Handbook of the Protestant Reformations, brydes der noget med den klassiske fortælling igennem inklusion af begreber som Paracelsianisme, pansophia, 'den lange reformation', og forestillinger om en universel reformation - men det er værd at bide mærke $i$, at dette sker i et kapitel med titlen 'Outsiders, Dissenters, and Competing Visions of Reform', som altså omhandler det og dem, der ikke rigtig medregnes eller ligefrem er konkurrenter (Hotson 2016).

Det helt store prisvindende værk om Reformationen The Oxford Encyclopedia of the Reformation bryder ligeledes på exceptionel vis med det klassiske billede ved næsten at have alt med, man kunne forestille sig, og indeholder da også flere indlæg om relevante skikkelser såsom Henrich Cornelius Agrippa von Nettesheim (1486-1535), Girolamo Savonarolas (1452-1494), Paracelsus, født Philippus Aureolus Theophrastus Bombastus von Hohenheim (1493/4-1541) og traditioner såsom 'kristen cabala', men måske sigende igen ingen direkte indlæg om Ficino, Giovanni Pico della Mirandola (1463-1494) født i Mirandola tæt på Modena, eller om hermetisme. I indlægget om Agrippa får vi kort at vide, at "Agrippa's importance thus stands outside the main lines of the Reformation. It rests on his Renaissance dream of rediscovering a submerged but divinely ordained wisdom that would both confirm and revivify Christianity." Altså er dette renæssance-reformprojekt kun en drøm om at forny kristendommen, der på sin vis står uden for direkte relevans for Reformationen - trods det at Luther vel også blot i princippet ønskede at genopfriske kirken frem for at bryde med den (Nauert 1996). 
Man kan derfor godt fra et strengt historisk perspektiv stille spørgsmål til den såkaldte klassiske og næsten altgennemtrængende reformationsfortælling - den religiøse, traditionelle, historiefortælling om Matin Luther og Reformationen.

\section{Spørgsmål til reformationsfortællingen}

Kommer vi som historikere ofte til at reproducere religiøse fortællinger eller religionernes fortællinger om sig selv? Dette relevante spørgsmål stilles fx af den tyske religionsforsker Jörg Rupke:

Thus, historians of religion - supposed to produce 'etic' accounts and striving to apply a methodology of understanding (Verstehen) to their scholarly objects - often uncritically adopt emic constructs and ignore the subjective and interpretive nature of these frameworks (Rüpke 2011, 285-309)

Når der fx fejres reformationsår i Danmark, fortælles Den danske Folkekirkes historie om Reformationen og det perspektiv, der ligger i denne; men vi skal være varsomme med ukritisk at adoptere den slags emic konstruktioner og derved ignorere de subjektive, fortolkningsmæssige, og identitetsskabende elementer, der ligger i den type rammeværk. Måske skulle vi snarere se, om vi kan opstille en form for etic historieperspektiv, der ikke nødvendigvis reproducerer religionernes fortællinger om sig selv og sine helte og heller ikke nødvendigvis afspejler den identitetssammenholdsforståelse, der ligger i fortællingerne. Rüpke skriver endvidere i denne sammenhæng i sit indlæg om 'history':

Thus, we continue to hear and read about 'the church of the martyrs' or about the 'victory' of Buddhism in its dealing with local Japanese cults in classical Japanese historiography [...], or of the 'Hellenisation of Christianity' and even about Christianity, Judaism and paganism (in the late antique Mediterranean context, for example) as if these were all separate, stable and unified entities which may or may not have influenced and interacted with each other in various ways (ibid., 289).

Reformation(en) som etic kategori kan således hurtigt blive en for tæt kopi af Reformationen i emic forstand. Der findes knap nok en etic reformationskategori for institutionelle forandringer i andre religioner, og hvis der er en, så hedder det ikke 'reformation', men 'skisma' (se fx Lewis \& Lewis 2009). Selv den nu mere nuancerede forståelse af omformningsprocessen og skismaerne i den romersk-katolske kirke i det 15.-16. århundrede og efterfølgende, som inddrager andre personer og tiltag end blot Luther, gør ofte dette for selektivt. Der er en rig pluralisme af tankegods i europæisk kultur, som kommer bedst til syne, hvis vi netop undgår at anskue det europæiske åndsliv og hermed også de etablerede religioner, såsom kristendommen, som alt for faste og entydige størrelser.

Denne pluralisme-betragtning gør sig gældende hos Kocku von Stuckrad med hans fokus på en europæisk pluralisme frem for en forståelse af religioner i mere afgrænsede og statiske kasser, der hver har deres egen faste identitet. Von Stuckrad skriver $\mathrm{fx}$, at "One characteristic of European history of religion is a two-fold pluralism: a pluralism of religious identities on the one hand, and a pluralism of various 
societal systems that interact with religious systems on the other" (von Stuckrad 2014, bagside, se også s. 7-22). Således er der dels Rüpke med hans tanke om, at historikeren ikke altid ubevidst skal reproducere religionernes fortællinger om sig selv, og dels von Stuckrad, som lægger vægt på, at netop hvis historikeren nedbryder de sædvanlige kasser og fortællinger, vil der åbne sig en større forståelse for den pluralisme, der også i det religiøse landskab har gjort sig gældende igennem Europas historie. Det er i dette teoretiske perspektiv, at reformationsprocessen, hvori Luther har sin plads, således vil blive undersøgt og forsøgt nuanceret.

\section{De oversete}

Med udgangspunkt i et alternativt historisk perspektiv på reformationsprocessen kan følgende spørgsmål derfor stilles: Hvorfor inkluderes visse personer, ideer, traditioner eller tiltag såsom Ficino, Pico della Mirandola, Johannes Reuchlin, (1455-1522), Agostino Steuco (1497-1548), Giordano Bruno (1548-1600), og Rosenkreutzer-fænomenet ikke nødvendigvis i de mere gængse historiske fortællinger om Reformationen, da flere af disse måske ofte oversete personer og deres idéer i Europas intellektuelle og religiøse historie har været med til at gøre fortællingen om Martin Luther og den fortsatte reformation/modreformation mulig? Pluralisme, inklusive de 'fremmede' før-kristne religioner, som disse personer og traditioner var interesserede $i$, har sjældent været medtaget som en konstituerende del af den kristne identitet - - men rent historisk set er sagen dog en anden.

Også med udgangspunkt i den før-reformatoriske renæssancetid kan dele af ovennævnte pluralisme rigt observeres i forskellige kontekster. De før-kristne græsk-romerske religioner forekommer blandt andet i kunsten hos en lang række malere, heriblandt hos Alessandro di Mariano di Vanni Filipepi (c.1445-1510), den florentinske maler bedre kendt som Sandro Botticelli i nogle af hans mest kendte værker såsom 'Venus' fødsel', 'Venus og Mars' og 'Primavera'. Den er tillige til at få øje på i andre kunstformer såsom i billedhuggerenes skulpturer, fx dem af den flamskfødte Giambologna (1529-1608), hvor de græsk-romerske fortællinger, myter og guder fortsat bliver brugt som motiver. Denne genfødsel med en forøget interesse for antikken og den ny tilstrømning af ældre religiøse, filosofiske og episke tekster var typisk for renæssancen. Helt centralt for renæssancetænkeres interesse for antikken var den mulige visdom og kundskab, som antikken indeholdt, og som måske kunne bruges som viden og inspiration til en ifølge dem tiltrængt fornyelse af kristendommen.

\section{Marsilio Ficino}

I denne sammenhæng er Ficino en helt central skikkelse. Ficino var allerede som en ung mand, der voksede op i Medici-familiens Firenze, overordentligt interesseret i sprog og i tekster fra antikken. Han var så optaget af disse og så begavet, at han hurtigt fangede Medici-familiens overhoved Cosimo de' Medicis interesse. Med et sponsorat fra Cosimo satte Ficino sig således for at oversætte blandt andet Platons samt mange af ny-Platonikernes værker og et stort materiale i øvrigt fra antikken fra græsk 
til latin. Han får efterfølgende også adgang til Corpus hermeticum, en samling af tekster fra sen-antikken, som man på dette tidspunkt antager indeholder en umådelig gammel visdom, måske en form for prisca theologia, fra den legendariske ægyptiske profet og vismand Hermes Trismegistus (Ebeling 2011, 59-64). Ficino og andre omkring ham blev voldsomt optagede af disse skrifter, fordi de måske netop kunne varsle om denne fornyede inspiration. Allerede på dette tidspunkt var Ficino påvirket af en figur, som betragtes som en af de mest anderkendte filosofer i den sen-byzantinske æra, Georgios Gemistos Plethon (1355/1360 - 1452/1454) fra Konstantinopel. Plethon havde tidligt i sit liv, allerede i tyverene, omgang med kredsen omkring Medici-familien i Firenze, og da Det Østromerske Rige faldt omkring 1453, hvor Konstantinopel blev overrendt af osmannerne, flygtede han til Firenze. Plethon var på sin egen måde også interesseret $\mathrm{i}$ at reformere kirken; men til forskel fra Ficino ønskede Plethon formentligt, at reformeringen skulle være en tilbagevenden til hedenskaben som den sande visdom (Hanegraaff 2012, 29-41), hvorimod Ficino betragtede den som noget, der kunne være med til at forny, revitalisere og måske genopdage den universelle og sande kristendom. De såkaldte fremmede elementer fra platonisme og hermetisme skulle altså på reformatorisk vis kunne hjælpe med at forstå den universelle kerne i kristendommen, som var blevet korrumperet. Det var for Ficino dette potentiale, der skulle frem i lyset, hvor han således så et reformatorisk potentiale i prisca theologia-tanken (Hanegraaff 2012, 51-53).

I renæssancen herskede stadig det nu tidligere, præ-moderne, historiesyn, som betragtede det at finde så langt tilbage i historien som muligt som ensbetydende med at komme tættere på den oprindelige kilde og dermed på den gyldne tidsalder - til forskel fra det moderne progressive syn, hvor det højeste ligger ude i fremtiden. I denne prisca theologia foreligger således en forestilling om en oprindelig teologi eller visdom, som er identisk med kristendommen i dens sande form, hvilket er i direkte forlængelse af argumenter fremført i den tidlige kristne apologetiske tradition i sen-antikken, hvor Justin Martyr (100-165) fx hævder, at kristendommen var tilstede allerede før Jesus Kristus' fysiske inkarnation, og at logos eller 'ordet' således også igennem tiderne havde inspireret en lang række andre fremtrædende personer såsom Sokrates og Platon (Rudbøg 2012, 80-81). Dette syn er således et forsøg på at vise, at kristendommen er gammel, og at den derfor kan forenes med hedensk filosofi. Ficino forsøger således at reformere kristendommen på baggrund af en universalisme relateret til platonisme og hermeticisme - modsat Luther, som ønskede at rense kristendommen for fremmede, hedenske elementer og senere kirkelige korruptioner.

\section{Pico della Mirandola, Savonarola og Reuchlin}

Ficinos yngre ven Pico della Mirandola fortsætter på mange måder i samme retning som Ficino og bliver endda fremhævet af Luther selv som en slags forgangsmand, der har været udsat for det samme som ham (Melloni 2017, 206). Som bekendt betragtes Pico della Mirandola ofte som udformeren af humanismens manifest med hans De dignitate hominis 'Om menneskets værdighed', som ret beset var ment som indledningen til hans såkaldte 900 teser - lidt i retning af Martin Luthers senere 95 teser hvor Pico della Mirandola således allerede før det 16. århundrede satte sig for at ville 
undersøge, hvordan alle antikkens forskellige esoteriske, filosofiske og religiøse traditioner i virkeligheden harmonerede, idet han mente, at der lå en universel visdom bag dem alle, som ikke blot kunne forenes med kristendommen, men kunne genfinde kristendommens fundamentale universelle sandhed og sammenhæng med andre traditioner. Pico della Mirandola var greve og havde rige økonomiske muligheder. Han inviterede derfor frit alle lærde, som kunne have lyst, til at komme til Rom for at diskutere hans 900 teser med henblik på en universal teologisk reform. Han ville naturligvis dække alle rejseomkostninger. Den ene af Pico della Mirandolas 900 sprængfyldte teser lyder således: 'Der er ingen videnskab, der mere grundlæggende kan overbevise os om Kristus' guddommelighed end Magi og Cabala' (Pico della Mirandola 1998, 495). Hans projekt om at samle Europas lærde under denne fane blev dog aldrig en realitet, da pave Innocens VIII den 20. februar 1487 nedsatte en kommission, der skulle undersøge hans teser og derefter den 5 . august samme år vedtog, at alle teserne skulle fordømmes og at udgivelse skulle forbydes. Teserne havde imidlertid allerede på dette tidspunkt vakt så stor opmærksomhed, at de samtidig var nogle af de første, der kom på Vatikanets nyoprettede liste over forbudte værker (Nielsen 1996, 20). Pico della Mirandola selv gik for en tid fri. Han flygtede til Paris, hvor han imidlertid på pavens opfordring blev fængslet af den franske konge Karl 8.; men med støtte fra Lorenzo de' Medici kom han under beskyttelse i Firenze.

Ficino og Pico della Mirandola var på ingen måder alene om deres idéer. Der var et væld af reformtanker og potentielle reformatorer i den centrale del af den italienske halvø. Da Pico della Mirandola ikke fik direkte succes med sit projekt, blev han en del af dominikanermunken, prædikanten og profeten fra Ferrara, Savonarolas (14521494) reformatoriske gruppe, der i en kort periode i Firenze gennemførte et oprør og en reformation. Savonarola mente, som Luther, der også havde læst Savonarola, at man skulle finde tilbage til den rene form for kristendom, og at man, på grund af den samtidige korruption af kirken, skulle afgive det meste af det verdslige gods og det meste af den litteratur, der fandtes, hvilket vakte stort røre i tiden (Weinstein 2011). Imidlertid døde både Pico della Mirandola og Savonarola blot to år efter, at deres beskytter Lorenzo de' Medici selv var afgået ved døden. Savonarola blev taget til fange, tortureret, hængt og brændt. Pico della Mirandola menes at være blevet forgiftet sammen med sin lærde ven poeten Angelo Poliziano. I 2007 blev deres jordiske rester, som er begravet i La Basilica di San Marco i Firenze, undersøgt af eksperter for, som i Tycho Brahes (1546-1601) tilfælde, at opklare, hvad de eventuelt havde indeholdt af giftstoffer på dødstidspunktet. Resultaterne viste, at i begge var der et højt indhold af arsenik, den foretrukne gift i samtiden.

Med baggrund i platonisme, hermetisme og Pico della Mirandolas tilføjelse af jødisk kabbalah spredte også reformationsidéerne sig som en del af renæssancens bevægelse mod nord. Den tysk-romerske Reuchlin, der også af Luther selv blev fremhævet som en forgangsmand, selvom han kun sjældent er med i fortællingen om Reformationen, besøger fx Pico della Mirandola i Rom i 1490, hvorefter han bringer mange af idéerne med tilbage til Det Tysk-romerske Rige. Reuchlin bliver på samme måde som Pico della Mirandola og andre i den præ-reformatoriske humanistiske re- 
formbevægelse, der på mange måder både udfordrer kirken og den skolastiske tilgang til viden, overordentligt optaget af det hebraiske sprog og af den jødiske esoteriske lære og udgiver bøgerne: De Verbo Mirifico (Basel, 1494), den første kristne hebræiske grammatikbog De Rudimentis Hebraicis (1506), De Arte Cabalistica (Hagenau, 1517) og det mere omfattende værk om hebræisk De Accentibus et Orthographia Hebræorum Libri Tres (1518). Forståelse af hebræisk bliver som bekendt en central del af Reformationen; men den banebrydende Reuchlin kommer i knibe i forhold til Dominikanerordenen, som dels finder Reuchlins forsvar af jøderne kættersk og dels ønsker at slå den humanistiske reformbevægelse ned. Selvom sagen imod Reuchlin trækker ud i mange år, går han i sidste ende fri. Andre humanister, som fx Agrippa, som er inspireret af Ficino, Pico della Mirandola og Reuchlin, tør dog knap nok udgive deres værker, hvorfor Agrippas De occulta philosophia libri tres, 'Tre bøger om okkult filosofi', der indarbejder antikkens traditioner og den jødiske kabbalah i ét samlet system, først blev udgivet i 1533, flere år efter at manuskriptet blev afsluttet.

\section{Paracelsus}

I Det Tysk-romerske Rige delte også den såkaldt 'medicinske Luther' (GoodrickClarke 2008, 74), Paracelsus, sådanne reformtanker, ikke kun inden for lægepraksis, som han er kendt for, men også inden for teologi. Om lægekundskaben mente han, at viden om sygdomme bør baseres på egen erfaring frem for på tradition. Fx kan man ifølge Paracelsus ikke vurdere om en person er syg, hvis man ikke kan se det med ens åndelige vurderingsevne. På forholdsvis provokerende vis forsøgte han således at gøre op med både den etablerede græske læge, kirurg og filosof Aelius Galenus (129-c.210) fra Pergamon, ofte kaldet Galen, og 'Lægevidenskabens Fader', Hippocrates fra Kos (460-c. 370). I Liber Prologi in Vitam Beatam (1533) kommer hans syn på datidens religion dog også til udtryk, hvor han blandt andet skriver, at 'hvis kristendommen af i dag havde domineret på Kristus' tid ville vi have set, at hverken Kristus eller Sankt Peter ville have tilladt denne katolske pragt, men ville have forhindret den gennem soning, bøn og prædiken' og at 'det er let at se, at tingenes tilstand ikke er som på Kristus' tid'. Han skriver også at 'hvis Kristus så imperiets nuværende vold og alle konger, prinser, herre, byer og landsdeles retfærdighed, ville han sige, at dette ikke var guds, men djævlen lov' (Goodrick-Clarke 1999, 149). Han mente i denne sammenhæng også, at dette ikke kunne fortsætte, og at tingene snart ville ændre sig. Han skrev derfor, at 'gud vil tillade en opdagelse af den største betydning, som dog må forblive skjult indtil Elias' komme' og at 'det er en sandhed, at der er intet skjult, der ikke vil blive åbenbaret, hvorfor et forunderligt væsen, som endnu ikke lever, vil efterfølge mig [...] og åbenbare mange ting' (citeret i Waite 1887, 34-35).

Paracelsus har således på samme måde som andre i tiden også denne tanke om, at en endnu større reformation ligger for dagen - ikke kun en reformation af kirken, men en form for reformation af hele verden. Også uden for det mere ortodokse miljø mod nord var der således en lang række mindre omtalte skikkelser, som på samme måde som Luther så reformation som relevant og ikke nok med det, at en endnu mere omfattende reformation ikke blot var nødvendig, men forestående. 


\section{Steuco og Bruno}

Selv i modreformationen fortsætter den hermetiske indflydelse og prisca theologia-tanken. Steuco, der var født i Gubbio i Umbria, skrev fx i 1542 et værk med titlen De perenni philosphia eller den evige filosofi. Egentlig begyndte Steuco sin karriere, da han i 1529-33 skrev en række værker imod både Luther og Erasmus, hvor han kritiserede deres tanker om Reformationen. Dette tiltrækker selvfølgelig pave Paul III's opmærksomhed, med hvem han kommer i kontakt, og han bliver efterfølgende ansat som bibliotekar hos paven i Vatikanet. Det paven blot ikke ved er, at her i Vatikanbiblioteket falder Steuco over Ficinos værker med tankerne om prisca theologia, Hermes Trismegistus og de hermetiske tekster og bliver overordentligt interesseret i disse, da han i stil med Ficino og Pico della Mirandola mener, at disse tanker kan bruges i forbindelse med modreformationen. Den universalisme, Steuco lægger for dagen, får på et tidspunkt overordentlig stor indflydelse på forskellige af samtidens koncilier og møder, særligt Tridentinerkoncilet i 1545, da han her ligefrem fungerer som stedfortræder for paven og taler på dennes vegne (Hanegraaff 2012, 68-73).

En anden central skikkelse i forhold til de såkaldte hermetiske reformationer var Bruno, som kom fra Nola i Kongeriget Napoli. Populært er han måske mest kendt som martyr for videnskaben i dennes opposition til kirken. Af oplysningstiden og positivisterne er han netop blevet ophøjet til at være en af den moderne videnskabs forgangsmænd, især fordi han i år 1600 endte sit liv ved at blive brændt på bålet på Campo dei Fiorii i Rom efter otte års proces, for blandt andet at hævde, som den polske matematiker og astronom Nicolaus Kopernikus (1473-1543) og andre havde sagt, at 'solen er i centrum'. Bruno var altså fortaler for det heliocentriske verdensbillede og også for, at universet er uendeligt. Bruno var dog i ordets egentlige forstand en enestående tænker, der var yderst kritisk over for kristendommens oprindelige og fortsatte samfundsmæssige degradering af civile dyder og civilret til fordel for absolutte religiøse værdier. Civilretten og dyderne er - ud over naturen - det guddommeliges fortsatte kontaktflade med mennesker og det, der gør, at vi overhovedet kan løfte os op fra det dyriske og blive guder på Jorden, som Bruno beskriver det i sin første London-dialog, Spaccio de la Bestia Trionfante 'Uddrivelsen af det Triumferende Bæst'. Titlen på værket blev formentlig tolket som en henvisning til paven, men værket tager netop form af en allegori om den nødvendige rensende reformation, som Bruno mente måtte begynde i himlen blandt konstellationerne, altså 'dyrebillederne', såsom store- og lillebjørn, da alle dyder på jorden tager afsæt i stjernes kræfter og kvaliteter. Det triumferende bæst er i dialogen summen af alle de negative kvaliteter, som stjernebillederne står for, som må erstattes af de rette dyder. Fx må store- og lillebjørns positive kvaliteter som sandhed, væren, og godhed således erstatte deformitet, falskhed og fejl (Bruno 1964, dialog I). Kristendommens og dermed også Paulus' oprindelige ovennævnte teologiske og samfundsmæssige fejl er det, der naturligt og konsekvent, ifølge Bruno, har ført til den 'onde engels', Martin Luthers, fremkomst og de mange voldlige splittelser, som reformationen havde medført i samtiden (Bruno 1964, dialog II). Trods sin kritik foretog Bruno dog rejser i protestantiske lande, udgav flere værker der, og blev ifølge nyere forskning også inspireret deraf (Gatti 2002, 145-166). 
Allerede i Frances Yates' banebrydende værk fra 1964 med titlen Giordano Bruno and the Hermetic Tradition vises det dog også, hvordan Brunos kritiske tankesæt på indgående måde var påvirket af forestillinger om ægyptiske, esoteriske traditioner, direkte inspireret af Corpus Hermeticum, som Bruno mente var centreret omkring soltilbedelse. Målet med en egentlig reformation af Europa måtte derfor være en tilbagevenden til den oprindelige gamle universelle ægyptiske religion - et restaureringsprojekt som han gav sig i kast med, men som blev dømt kættersk af kirken (Haaning 2001, 330-38, 372-78; Yates 1964, 215-31, 253, 278-80). I processen, der ledte til Brunos henrettelse, var det dog ikke entydigt enten naturfilosofiske, hermetiske, eller kristenteologiske problemstillinger, der lå til grund, som forskellige forskergenerationer har argumenteret for, men en kombination af dem alle (Finocchiaro 2002, 51-96). Igen er historien noget mere nuanceret end de endnu gængse billeder, der ofte fremhæves af Bruno som den store heltemodige videnskabsmand og filosof (Berggren 2002, 17-49). Han var som her antydet også religionskritikker og en reformator, der søgte en hermetisk inspireret reformation.

Lige på den anden side af år 1600 ser vi fortsat fremkomsten og videreførelsen af hermetiske og beslægtede traditioners indflydelse i form af reformatoriske projekter, særligt med fremkomsten af Rosenkreutzer-bevægelsen, som bygger på Paracelsus' lære og de hermetiske tanker fra renæssancen med en stærk anti-katolsk tilgang, samtidig med, at de relaterede til den originale cistercienserabbed Joachim af Fiores (c. 1135-1202) tidsalder-lære, der mente, at en ny tidsalder var lige om hjørnet efter en mere generel reformation af hele verden (McIntosh 1980, 36-41; Waite 1887, 34).

\section{Afrunding}

At de her nævnte skikkelser nævnes i fortællinger om Reformationen og den fortsatte reformationsdebat efter Luther, hører endnu til sjældenhederne, selvom deres liv og idéer historisk set udgør væsentlige kilder til netop reformationstiden og til hele den debat, der har ført til Reformationen. I det omfang disse tænkere er blevet omtalt, er det således oftest $\mathrm{i}$ andre sammenhænge og kontekster. Spørgsmålet er imidlertid, hvorfor det forholder sig på denne vis? Måske forholder det sig sådan, at de protestantiske og katolske fortællinger stadig har en væsentlig indflydelse på, hvordan Reformationen og modreformationen studeres, og på den fortælling der stadig bruges? Som vist ses, at pluralisme, inklusive det der anskues som fremmed, stadig enten implicit eller eksplicit marginaliseres på samme måde, som det negligeres af den klassiske kristne diskurs. De reformtanker, der var inspireret af hermetisme- og prisca theologia-forestillingen, var dog netop et forsøg på integrationen af 'fremmede' elementer, hvilket ikke traditionelt hører med til kristendomshistorie og kristen identitet. Men spørgsmålet er, om historikere så heller ikke skal medtage disse i debatten omkring Reformationen? Her er svaret, at vi netop ved hjælp af pluralisme-linsen, der træder uden for traditionelle religiøse identiteter, og en kritisk holdning til et begreb som Reformationen, bør revurdere og inkludere den rigdom af forskelligartede tanker, der 
udgør europæisk kultur, såsom hermetisme og prisca-theologia, som i denne henseende har været en forholdsvis overset del af den historiske kompleksitet, der ledte op til Reformationen, modreformationen, og de fortsatte reformationstiltag.

\section{LITTERATUR}

Berggren, Lars

2002 "The Image of Giordano Bruno", in: Hilary Gatti, Giordano Bruno, Philosopher of the Renaissance, New York: Routledge, 17-49.

Bruno, Giordano

1964 The Expulsion of the Triumphant Beast, ed. og overs. Arthur D. Imerti, New Brunswick: Rutgers University Press.

Dixon, C

2012 Contesting the Reformation (Contesting the past), Oxford: Wiley-Blackwell.

Ebeling, Florian

2011 The Secret History of Hermes Trismegistus: hermeticism from ancient to modern times, Ithaca: Cornell University Press.

Finocchiaro, Maurice A.

2002 "Philosophy versus Science versus Religion: the Trial of Bruno and Galileo" in: Hilary Gatti, ed., Giordano Bruno, Philosopher of the Renaissance, New York: Routledge, 51-96.

Gatti, Hilary

2002 "Giordano Bruno and the Protestant Ethic" in: idem, ed., Giordano Bruno, Philosopher of the Renaissance, New York: Routledge, 145-166.

Goodrick-Clarke, Nicholas

1999 Paracelsus, Essential Readings, Berkeley, CA: North Atlantic Books.

Goodrick-Clarke, Nicholas

2008 The Western Esoteric Traditions: A Historical Introduction, Oxford: Oxford University Press.

Haaning, Aksel

2001 Naturens Lys: Vestens naturfilosofi i højmiddelalder og renæssance 1250-1650, København, C.A. Reitzels Forlag.

Hanegraaff, Wouter J.

2012 Esotericism and the Academy, Cambridge: Cambridge University Press.

Hotson, Howard

2016 "Outsiders, Dissenters, and Competing Visions of Reform", The Oxford Handbook of the Protestant Reformations. https://doi.org/10.1093/oxfordhb/9780199646920.001.0001/oxfordhb9780199646920-e-33.

Leppin, Volker

2006 "Reformation" in: Kocku von Stuckrad et al., eds., The Brill dictionary of religion, Leiden: Brill, 1596-97.

Lewis, James R., \& Sarah M. Lewis

2009 Sacred Schisms: How Religions Divide. Cambridge: Cambridge University Press.

McIntosh, Christopher

1980 The Rosy Cross Unveiled: The history, Mythology and Rituals of an Occult Order, Wellingborough, Northamptonshire: The Aquarian Press.

McGrath, Alister E.

1998 Historical Theology: An Introduction to the History of Christian Thought, Oxford: Blackwell Publishers. 
Melloni, A.

2017 Martin Luther, A Christian between Reforms and Modernity (1517-2017), Berlin; Boston: De Gruyter.

Nauert, Charles G.

2005 "Agrippa, Heinrich Cornelius", in: Hans J. Hillebrand, ed., The Oxford Encyclopedia of the Reformation, online: Oxford University Press.

Pico della Mirandola

1996 Om Menneskets Værdighed, oversæt., indl. og noter Jørgen Juul Nielsen, København: Museum Tusculanum.

1998 Syncretism in the West: Pico's 900 theses (1486), the evolution of traditional religious and philosophical systems, in: S. A. Farmer, ed. Medieval and Renaissance texts and studies 167, Arizona: Arizona State University.

Rudbøg, Tim

2012 Blavatsky's Theosophy in Context: The Construction of Meaning in Modern Esotericism, PhD thesis. Exeter, University of Exeter.

Rüpke, Jörg

2000 "History", in: Michael Stausberg \& Steven Engler, eds., The Routledge Handbook of Research Methods in the Study of Religion, London, New York: Routledge, 285-309.

Stuckrad, Kocku von

2014 Locations of Knowledge in Medieval and Early Modern Europe: Esoteric Discourse and Western Identities, Leiden: Brill.

Waite, Arthur Edward

1887 The Real History of the Rosicrucians, London: George Redway.

Wallace, P.

2004 The long European Reformation, religion, political conflict, and the search for conformity, 1350-1750, Houndmills, Basingstoke: Palgrave Macmillan.

Weinstein, Donald

2011 Savonarola, the rise and fall of a Renaissance prophet, New Haven: Yale University Press.

Yates, Frances

1964 Giordano Bruno and the Hermetic Tradition, London: Routledge and Kegan Paul.

Tim Rudbøg, lektor, ph.d., centerleder Copenhagen Center for the Study of Theosophy and Esotericism (CCSTE), Institut for Tværkulturelle og Regionale Studier, Københavns Universitet timrudboeg@hum.ku.dk 